går efter ikke-anonyme. Kan de ikke få det, går de til udlandet. Der er kun en Salomonisk løsning på dette meget gamle problem: der skal være adgang til begge typer donorer i et samfund.

Jeg kan tilføje at Cryos stod for $100 \%$ af leverancerne i Norge fra 1995-2005, fordi man ikke selv kunne skaffe donorer i Norge. Det kan man stadig ikke, kun i meget lille udstrækning. Vi får rapporteret omkring 150 graviditeter om året på norske recipienter, og det tal har været stabilt også efter 2005, så lovændringen i Norge har ingen effekt haft overhovedet. Vi har fået rapporteret 2372 graviditeter på Norske recipienter, men kun ca. halvdelen er registreret fra Norske sygehuse: 1 189. Dette viser, at folk blot tager til Danmark.

Der er konsensus om, at åbenhed er godt, men det er kun mht. til at fortælle barnet om sin tilblivelse. Det betyder ikke, at man ikke skal have anonyme donorer. Det vil i øvrigt aldrig kunne sikres at børn får deres biologiske forældre at vide. Vi ved at mellem 5-10\% i Danmark ikke har den far, de tror de har. Det er dokumenteret via uselekterede data. FN's Børnekonvention siger intet om det genetiske familieskab. Det kan tolkes som plejforældre, surrogatforældre, sociale forældre, osv.

$\mathrm{Vi}$ har en forpligtelse som samfund til at beskytte anonymiteten for de donorer og de recipienter, som vi har lovet anonymitet. Det må gælde for altid.

En andet forhold er, at anonymiteten kan være svær at sikre i fremtiden, med fora som donorsiblingregister.com og 23 andMe.com, men det ændrer ikke ved, at vi som samfund fortsat skal sikre anonymiteten som vi har lovet.

Min opfordring til de ansvarlige i Norge er, at vågne op og se virkeligheden i øjnene. Forbud mod anonym donation er som forbud mod abort. Det er en smuk tanke, men den kan ikke realiseres. Ansvarlighed er, at sikre ordentlige adgang til sikker behandling for alle i samfundet $i$ eget land. Norge bliver på sigt nødt til at fjerne forbudet mod anonymitet. Før det sker, vil problemet ikke være løst.

Ole Schou

os@cryosinternational.com

Ole Schou (f. 1954) er administrerende direktør Sædbanken Cryos International

Forfatteren er administrerende direktør i Sædbanken Cryos International.

Litteratur

1. Elgjo GI. En oppfordring til anonyme sæddonorer. Tidsskr Nor Legeforen 2015; 135: 2030.

\section{G.I. Elgjo svarer:}

Takk for din kommentar! Sæddonasjon er i utgangspunktet hjelp til infertile par. I tillegg er det et sosialt eksperiment vi ikke fullt overskuer. Hvorledes virksomheten påvirker donor, mottagere og donorbarn endrer seg i takt med samfunnsutviklingen. Mye er imidlertid lært på veien, og den kunnskapen bør vi bruke.

Min artikkel kritiserer verken Rikshospitalets donasjonsprogram som jeg var en del av eller donorinseminasjon som sådan. Men i løpet av de siste 30 år har vi evidens på at åpenhet er bedre. Å gå tilbake til anonym donasjon i Norge ville være et tilbakeskritt: En feil rettes ikke ved å gjøre en ny.

Det er viktig at myndighetene kjenner til de forhold du beskriver, som fertilitetsturisme. Eller privat anonym sæddonasjon, som forekommer utenfor loven i Norge i dag. Flere steder i verden er det avdekket tilfeller av at en enkelt donor har unnfanget hundrevis av barn, også ved universitetsklinikker. Fordi virksomheten både er tabubelagt og har skjedd under dekke av anonymitet kan slik uheldig praksis forekomme.

Flere viktige endringer gjør at man må tenke nytt: En av dem er de frivillige registrene. De møter et behov helsevesenet ikke har dekket. Det eldste er 15 år gammelt - donorer rekrutteres stadig, likevel. Samtidig har tilgjengelighet og reliabilitet til DNA-tester øket. En siste faktor er erkjennelsen om hvordan det går med donorbarna, dokumentert gjennom faglitteratur som ikke fantes på 80-tallet.

All kunnskap tilsier at dersom man har mulighet til å velge bør man velge åpenhet. Kanskje verken myndigheter eller klinikker er flinke nok til å informere sine kunder om fordelene ved åpenhet og ulempene ved anonymitet. Samfunnet har en del myter omkring åpenhet som må avlæres. Jeg etterlyser obligatorisk undervisning av donorsøkende par på samme måte som potensielle adoptivforeldre må underkaste seg obligatorisk opplæring før man får adoptere åpent.

Folk vet at blodgiving er nyttig og redder liv, men det promoteres i liten grad hvor nyttig og ufarlig sæddonasjon er, og hvor stort behovet er. Positiv opplysning og avmystifisering er den beste vei å gå.

Jeg erkjenner at det er skapt et helsebehov i kjølvannet av den aktiviteten jeg var en del av. For meg er det en del av legegjeningen å møte det helsebehovet.

\section{Geir Ivar Elgjo \\ ge-elgj@online.no}

Geir Ivar Elgjo (f. 1960) er overlege i anestesiologi ved Operasjons- og intensivklinikken, Universitetssykehuset Nord-Norge. Ingen oppgitte interessekonflikter.

\section{Re: Et ulogisk og uheldig bivirkningsbegrep}

Slørdal \& Christoffersen skriver i en kommentarartikkel i Tidsskriftet at den nye definisjonen av hva som er et medikaments bivirkning er ulogisk og uheldig (1).

Bivirkningsdefinisjonen er utvidet til også å omfatte bivirkninger som skjer ved anvendelse utenfor godkjent bruksområde, for eksempel ved godkjenningsfritak, overdose, feilbruk, misbruk og feilmedisinering, og ved yrkeseksponering. Slik Legemiddelverket ser det, er dette er en fornuftig og ønsket utvidelse av definisjonen der formålet er å trygge pasientene.

I 2012 ble det innført et nytt lovverk om legemiddelovervåking i Europa. Hensikten var å få et mer proaktivt, effektivt og transparent overvåkingssystem. Spontanrapporteringssystemet for bivirkninger er bare en del av denne overvåkingen. Bivirkningsdefinisjonen ble endret for å styrke helheten i overvåkingssystemet, og EUregelverket er senere implementert i norsk lovverk. Alle europeiske land benytter nå den samme bivirkningsdefinisjonen. Dette er helt nødvendig for å kunne samarbeide om å raskest mulig identifisere og ta tak i ukjente problemer. Regelverksendringene ble utarbeidet etter grundige faglige diskusjoner, og det ble gjennomført formelle høringsprosesser både i EU og i Norge.

Det at en utvidet definisjon medfører økt tilstrømming av bivirkningsmeldinger, er en ønsket utvikling. Et konkret eksempel på at den utvidete definisjonen gir bedre pasientsikkerhet er den såkalte metadonsaken fra 2013/2014 (2, 3). Legemiddelverket mottok flere meldinger om bivirkninger som kunne skyldes feilbruk/misbruk av metadonmikstur. Det ble mistenkt at rusavhengige injiserte legemidlet i stedet for å innta det per os. Hos disse pasientene ble det funnet avleiring av et hjelpestoff, povidon, $i$ indre organer og vev, noe som medførte alvorlige skader og i enkelte tilfeller død. På bakgrunn av bivirkningsmeldinger om disse hendelsene, ble Legemiddelverket oppmerksom på problemet og kunne agere - både nasjonalt og på europeisk nivå. Dette ville ikke vært en bivirkning etter gammel definisjon, og ville derfor ikke blitt registrert i meldesystemet.

Slørdal \& Christoffersen påstår at vi «løper risikoen for å gjemme de egentlige bivirkningene i en høystakk av misbruk, overdoser, feilbruk etc.» Som vi har eksemplifisert over, anser vi ikke «de andre» meldingene for å være unyttige, snarere tvert imot. I tillegg har vi i dag meget gode systemer for å sortere ut hva som er viktig når vi utfører signalarbeidet, dvs. arbeidet med å oppdage nye bivirkninger. 